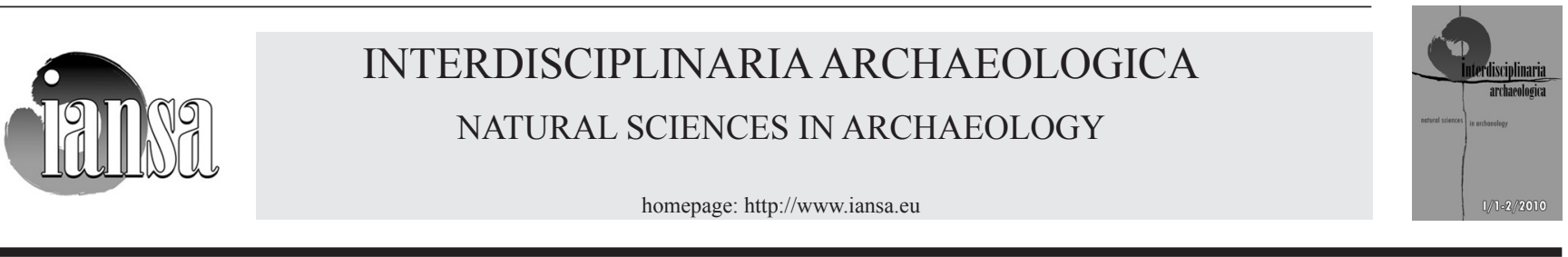

News and Views

\title{
Interpretation of Palaeopathological Finds
}

\author{
Lenka Vargová, Ladislava Horáčková* \\ Division of Medical-Anthropology, Department of Anatomy, Medical Faculty, Masaryk University, Kamenice 3, 625 00 Brno, Czech Republic
}

\section{ARTICLE INFO}

\section{Article history:}

Received: 6 December 2010

Accepted: 28 February 2011

\section{Key words:}

palaeopathology

early modern times

archaeological finds

case studies

\begin{abstract}
$A B S T R A C T$
In recent years a number of medical anthropological analyses of skeletal remains (an integral component of which was evaluation of pathological change) from various historical periods was conducted at the Department of Medical Anthropology, Anatomical Institute, Faculty of Medicine at Masaryk University. The main objective of this article is to provide a summary of all diagnostic experience with palaeopathological finds, and research conducted into the optimum methodology for interpretation. The same procedures as those commonly used in medical practice (1. history, 2. objective examination, 3. working diagnosis, 4. differential diagnosis, 5. final diagnosis) are applied to palaeopathological diagnoses, but modified in consideration of the peculiarities of skeletal sets. Since the possibility of obtaining anamnesis data and of applying common methods of medical examination are both substantially limited in the study of osteological material, it is also necessary to collect all available literary and iconographic data sources. As a result palaeopathological diagnostics requires extensive knowledge from several branches of science, particularly anthropology, medicine, and history.
\end{abstract}

\section{Introduction}

The analysis of palaeopathological finds consists of determining a diagnosis based on the symptoms found on a skeleton or mummified body. That is why it is necessary to select procedures similar to those used in ordinary medical diagnostic practices, namely:

1) case-history, 2) objective examination, 3) working diagnosis, 4) differential diagnosis, and 5) final diagnosis.

Palaeopathological diagnostics comes with certain problems and therefore requires extensive knowledge from several scientific branches, especially anthropology, medicine, and history.

\section{Palaeopathological case-history}

The case-history is the inevitable opening of each medical examination. It is a set of data about the current health

"Corresponding author. E-mail: lhorac@med.muni.cz condition of a patient and illnesses suffered (personal medical history). It follows the genetic load (i.e. the occurrence of hereditary diseases of blood relations - family medical history), identifies information about subjective and objective symptoms of the current disease, and its treatment (medical history). These are sorted chronologically and enable the identification of risk factors that could be causally related to the actual illness (working case-history, following the patient's living habits and social and environmental conditions).

However, the possibilities of acquiring anamnestic data are considerably limited in palaeopathological studies. A number of problems with developing a palaeopathological case-history are presented in the work of Vargová and Horáčková (2008, 242-251).

In palaeopathology the standard anthropological analysis of skeleton remains using classic anthropometric and morphoscopic methods can substitute for a personal medical history to some degree (see Breitinger 1937; Martin, Saller 1957; Howells 1964; Bach 1965; Černý 1971; Lovejoy 1985; Ubelaker 1987; Knussmann 1988; Florkowski, Kozlowski 1994; Loth, Hennenberg 1996; Stloukal et al. 1999). 


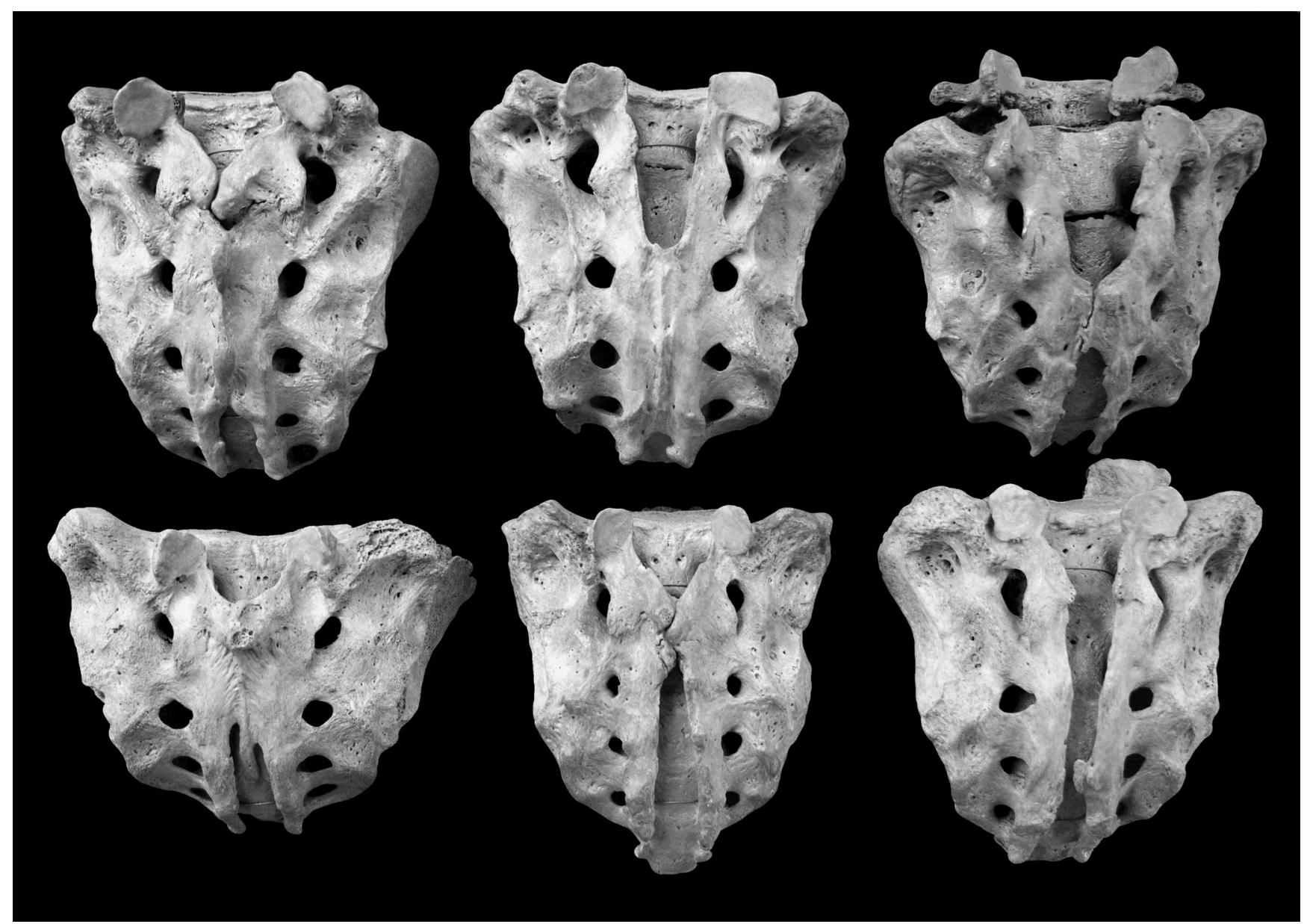

Figure 1. Sacral bones with different types of spina bifida (Professor Karel Žlábek Museum of Anatomy, Department of Anatomy, Faculty of Medicine, Masaryk University.

In this way it is generally possible to estimate biological age, gender, minor normative abnormalities and - based on the skeleton robustness - the overall body constitution of the examined individual. These pieces of knowledge might be essentially important for a differential diagnosis.

Quite a number of diseases occur only at a certain age, or change character depending on the individual's age. Both morphological and physiological characteristics are specific to age, over the course of ontogenetic development, when the human organism undergoes quite a number of changes.

The relationship of illness symptoms to the affected person's age can be shown using the example of vitamin D deficiency. In childhood this manifests with rickets and clear deformations of the extremities of long bones, whereas in adulthood it causes osteomalacia with considerable osteoporosis and imperceptible bone shape changes.

In other cases, the occurrence of a certain disease may relate to gender. Internal frontal hyperostosis, for example, is found predominantly in women.

The stature estimation carried out routinely in anthropology may, in cases of extreme values, lead to suspicions of one of the endocrinous diseases (gigantism or nanism), for which growth disorders are symptomatic (Vargová, Horáčková 2008, 242-251).
It is also necessary to search for all diseases suffered throughout life in a personal medical history. If no literature or iconographic sources exist, then traces of "nonspecific" stress symptoms in skeletons (e.g. the Harris' line, cribra orbitalia or hypoplasia of tooth enamel or dentin) may represent a source of information, through with considerable limitations. These symptoms inform only about non-specific illnesses suffered. A whole spectrum of origins exists, for example long term starvation or unbalanced diet, infectious febrile diseases of various etiologies, diarrhoeal diseases accompanied by a loss of liquids and minerals, excessive physical exertion from hard work, deprivations of war, serious injuries, and endocrine illnesses. That is why nonspecific stress symptoms of skeletons remain proof only of a suffered physical load connected with a slowing down or a disorder of the metabolism of bones and the mineralization of teeth. Therefore, they are the subject of speculation only in the absence of any other pathological changes in a skeleton.

Acquiring data from a family medical history is also problematic in palaeopathology. Studying genealogical trees and related contemporary written and iconographical sources may provide such data in cases of historically significant personalities. A family medical history can be substituted by a population medical history in cases of unknown individuals 
from burial-grounds without an exact identification of persons buried in particular grave pits. Information about the health and life conditions of the whole population may lead to the revelation of an individual's disease. Data about alimentation, food production, type of dwelling and routinely used tools are essential. In cases of injuries, data about conflict, types of weapons used and methods of warfare are also important.

Pieces of knowledge about the general health service level and treatment possibilities in the historical period under study also belong to the case-history of the disease under investigation. It is possible to search skeletons under examination for traces of routinely used medical interventions or chemical proofs of medications used at that time.

Valuable pieces of information about the most frequent diseases can be also acquired by studying chronicles, registers, mandatory medical reports from imperial-royal public hospitals, etc. Good quality portraits or sculptures may also depict morphological changes characteristic for a certain disease in some cases.

Searching all traceable hazard factors having causal relation to the examined illness is another part of the casehistory. Natural conditions, natural disasters and epidemics belong to such factors.

A specific problem in developing a palaeopathological case-history is identifying the historic time period of the occurrence of a suspected illness. For example, in Europe, leprosy mostly spread in the $13^{\text {th }}$ century, syphilis at the end of the $15^{\text {th }}$ and in the $16^{\text {th }}$ century, and tuberculosis culminated in the $19^{\text {th }}$ and beginning of the $20^{\text {th }}$ century.

\section{Objective examination}

A detailed macroscopic examination of the skeleton is the most important part of palaeopathological diagnostics, based on which it is possible to identify all morphological bone changes. It is always necessary to proceed systematically and to examine all preserved skeletal remains, including small fragments. Attention must be also paid to the content of cavities, so that calcified lymphatic nodules, urinary stones and gallstones, parts of fatal instruments or weapons, etc. are not potentially omitted.

It is always necessary to assess morphological bone changes first, i.e. if it is just a standard deviation (a variety), or a symptom of a certain disease. It is very difficult to distinguish a variety from a congenital anomaly in the palaeopathology of some cases, as sometimes only the functional status may be the main criterion. A cleft spine (spina bifida, rhachischisis) is such an example. If a crevice remains between both halves of the vertebral arch of one or more vertebrae and the spinal canal is open (Figure 1). It can be assessed as a variety, if the cleft is of a smaller extent and does not cause problems to the affected person. The more extensive defects are usually accompanied by a spinal cord prolapse and its meninges and it is unequivocally a congenital anomaly. Simply the fact that the majority of individuals with spinal cord prolapse die shortly after birth, without proper treatment, leads to the assumption that cases of spina bifida found in skeletons of adults from archaeological contexts are only harmless varieties (Horáčková et al. 2004, 42-47).

An integral part of objective examination is making the documentation as complete as possible. Observed pathological changes should be recorded mainly in writing, describing for example the precise location of pathological focuses on the skeleton, their frequency, size, edges, and overall nature. It is also necessary to prepare high quality photo documentation, possibly with a schematic sketch. It is always necessary to assess the whole skeleton for the sake of completeness (eventually to even take note of individual bones without a pathological finding).

\section{Working diagnosis}

It is possible to guess at one or more illnesses that could be the probable cause of these changes, based on the objective skeletal examination and the preliminary assessment of observed pathological changes. Each of these possible (suspected) illnesses represents a separate working diagnosis, which has to be either confirmed or rebutted by a series of further examinations. This component of diagnostics benefits from the engagement of professionals competent in paleopathology and medicine: optimally a medically trained anthropologist and a pathologist trained in anthropology.

\section{Differential diagnosis}

It is the task of differential diagnostics to consider all diseases with similar symptoms based on pathological skeletal changes and to clarify their real cause by other examination procedures - to determine the final diagnosis.

From amongst a number of imaging methods common in clinical practice, the use of classic X-ray or CT scans are prefered for palaeopathological skeletal examinations. It is also possible to conduct a histological examination of bone tissue samples with a light or electron microscope, a chemical analysis of bones or a serological examination depending on the indication. DNA proof of pathogenic micro-organism in a bone sample using the PCR (Polymerase Chain Reaction) method can be considered a reliable confirmation of an infectious illness.

In palaeopathology, the applicability of the abovementioned laboratory methods is significantly limited by the degree of preservation of the skeletal remains, by their proper exhumation at archaeological excavations, preservation, conservation, proper long-term storage and handling during mechanical cleaning, gluing of the bone fragments, and assessment. The distortion of genetic examination results occurs most often through the conservation of bones using various fixatives, and by the contamination of samples from the ambient air, in case of compact bone impairment, etc. It is not possible to rely on serology in bones exposed to wet conditions and to action of molds. The evidentiary value of a 
chemical analysis of bone tissue depends on the composition of soil in which the skeleton was buried, since it may cause bones to decalcify or allow substances from the surrounding soil to penetrate into them.

As a result differential diagnostics in palaeopathology is very difficult in many cases. It requires broad interdisciplinary knowledge as well as rich experience with the processing of skeletal remains. For the sake of clearness, several examples of differential diagnostics as practised at the Medical Anthropology Department of the Anatomic Institute of Faculty of Medicine of the Masaryk University will be presented.

\subsection{Examples of differential diagnostics}

Deliberations and a consequent selection of examination method at the finding of a vertebral block will be the first example. The merger of two or more adjacent vertebrae into one formation is referred to as vertebral block. This condition may occur due to a number of reasons. It may be just an insignificant variety, but also a congenital spine developmental defect; such as, spondylosis (Forestier's disease being one of its forms), Bechterev's disease (spondylarthritis ancylopoetica), Pott's disease (tuberculous spondylitis) or a post-traumatic complication of a vertebrae fracture.

The full or partial fusion of the fifth lumbar vertebra with sacral bones (so-called lumbar vertebra sacralization) is considered to be an insignificant deviation from standard. It affects approximately $4.2 \%$ of our population according to Čihák $(1987,114)$ and is regarded generally as a progressive variety - being the manifestation of human backbone reinforcement after conversion to bipedia.

Congenital vertebral blocks are caused by a spinal segmentation disorder. They are a relatively frequent finding with very diverse forms. An intervertebral disc base is absent in the simplest cases. The adjacent terminal plates of vertebral bodies fully fuse. Another time, a crevice corresponding to the hypoplastic intervertebral disk can be observed at the vertebral bodies and the vertebral bodies are connected only on the perimeter. It is a significant fact from the viewpoint of the differential diagnostics, if the vertebrae have a normal form with a smooth surface in the merger level and a normal shadow structure in the X-ray image in case of congenital blocks. Very often, spondylotic changes occur at the border between the block and the adjacent normal vertebrae due to an anomalous functional load. A connection of congenital blocks with various other abnormalities of the vertebrae is also characteristic (Horáčková et al. 2004, 42-47). We can present as an example of a congenital block from our discoveries the fusion of cervical vertebrae of a grown-up individual from the Old Slavonic burial ground in OlomoucNemilany (Vargová et al. 2002, 145-155).

Spondylosis is the most frequent reason of the origin of vertebral blocks of various dimensions. The notion refers to the degenerative-productive changes of the spine that, as a rule, affect older individuals. They are therefore considered a symptom of the natural ageing of connective tissues.
The bony projections - osteophytes - appear on the edges of terminal plates of vertebral bodies and they merge with one another in the more advanced spondylosis stage. In the case of Forestier's disease, a special spondylosis form, the blocks consist of more vertebrae as a rule, the merged osteophytes make a massive bone tissue strip that resembles a wax curtain. The longitudinal shadow corresponds to the massive bony strip on an X-ray image, the structure of which usually corresponds to the spongious bone. Intervertebral crevices maintain their normal size. The form as well as the structure of vertebral bodies remain also unchanged, or traces of a diffusion osteoporosis appear in the case of a long time immobilization of a part of the spine (Horáčková et al. 2004, 53-60).

Bechterev disease may be the reason for the fusion of vertebrae or even the whole spine. It is a chronic inflammation of connective tissues of the spine similar to rheumatoid arthritis. The rheumatoid inflammation of Bechterev disease usually initially affects both sacro-coxal joints, which results in their total anchylosis. The process advances from the sacral area upwardly to the whole backbone or its larger part then. The entire backbone is accreted and resembles a "bamboo stick" in the final stage of the illness.

The affliction of two to four adjacent vertebrae, caudalthoracic or cranial-lumbar ones mostly, is characteristic for vertebral blocks in case of the Pott's disease. The tuberculous inflammation impairs the spongious trabeculas inside vertebral bodies to such an extent that their total destruction and transformation to a cheesy substance (casein) gradually occurs. After the liquefaction of the casein the vertebrae bodies contain large inside abscesses, which are not able to withstand an ordinary mechanical load, crack in their ventral part, and thus gain a wedge-shaped form. The inflammatory process also affects the intervertebral disc, such that a bony accretion occurs place between two deformed adjacent vertebrae. It results in the formation of a vertebral block with an angular backbone curvature - the tuberculous hunchback referred to as a gibbus. The cheesy substance may flow down as far as to the coxal pit in some cases and cause a new bone formation in the area of the descent due to the periost irritation - a converging abscess (Horáčková et al. 2004, 97-103).

A comminuted fracture of vertebra body caused by compressing the spine in its axial direction is a rarer cause of vertebral block formation. It is caused by the cranial vertebra, which breaks the body of the lower vertebra into several fragments with its lower front edge. One of vertebrae at the transition of the thoracic and lumbar backbone is affected most frequently. A heavy post-traumatic spondylosis originates in consequence of the comminuted fracture as a rule. The body of the afflicted vertebra is usually noticeably lower and wider in an X-ray image, having a wedge-shaped or more or less irregular form. The intervertebral disc, bridged by osteophytes, is lowered compared to other backbone sections. This type of vertebral block is considerably bent in angular way frequently and results in a heavy backbone cyphosis (Horáčková et al. 2004, 70-72). 
Examination procedures and deliberations in the case of a defect found in the nasal and palate area is another example of differential diagnostics. There may be several reasons that a palatonasal destruction may exist, such as, a congenital cleft of palate and jaw, a specific inflammation (syphilis or leprosy), the destruction of the facial skeleton by a malign tumour from surrounding tissues, or even injury (Figure 2).

The congenital cleft of the upper lip, jaw, and possibly of the whole palate is a disorder of the embryonal development. The cleft can be one sided or two sided. The defect creates an undesirable connection between the nasal and oral cavities; it has the character of a crevice with rounded edges usually. The cleft can be either of a small extent reaching to the level of foramen incisivum (cleft of the upper jaw) furthermost, or of a larger extent (cleft palate). We mostly find smaller clefts in archaeological skeletal sets because the food intake was a problem in more serious cases. Affected individuals often died in early infancy without corrective surgery.

It is always necessary to take leprosy into consideration in an instance of palatonasal destruction, too, especially in cases of medieval skeletons. In which case there is an initial atrophia of the spina nasalis anterior, followed by a laterally symmetric destruction of alveolar ridges of the upper jaws that advances from the median plane in the lateral direction. The alveoli of incisive teeth are impaired to such a degree in the advanced stage of the illness that the teeth are lost. The hard palate can be also affected, which manifests itself by its thinning or total perforation, and the nasal septum and structures on the lateral wall of the nasal cavity may also be destroyed to various extents. The edges of apertura piriformis are usually resorbed and rounded symmetrically by the reparation process. The confirmation of the presence of Mycobacterium leprae DNA in bone samples, by means of genetic examination, can be considered a reliable and sufficient proof of leprosy. Traces of the invader are not necessarily preserved all the times, so a negative test result does not rule out the leprosy.

Syphilis was a very frequent reason for palatonasal destruction on skulls of Early Modern skeletal sets, where the affliction was caused by gumma spreading from soft facial tissues to the skeleton. The destruction process could perforate the hard palate and descend to the alveolar processes of upper jaws. Nasal bones might also be deformed (saddleback nose). Traces of the healing process or possible other syphilitic symptoms at the skeleton as described by Hackett (1976) are also significant for a differential diagnostics.

The palatonasal destruction can be also caused by a tumour. Malign tumours originating in adjacent soft tissues may destroy bones by osteoclastic reabsorption at their invasive growth. The developed lytic niduses are of irregular, even bizarrely shaped, their contours are mostly sharp mostly. There are no traces of healing (Strouhal, Němečková 2008).

Splanchnocranium bones may be also deformed by a benign tumour that affects the bones by pressure. It is possible to estimate the tumour form, and possibly the place from which the growth started, according to the shape of the imprint (cavity). A detailed radiology examination of the
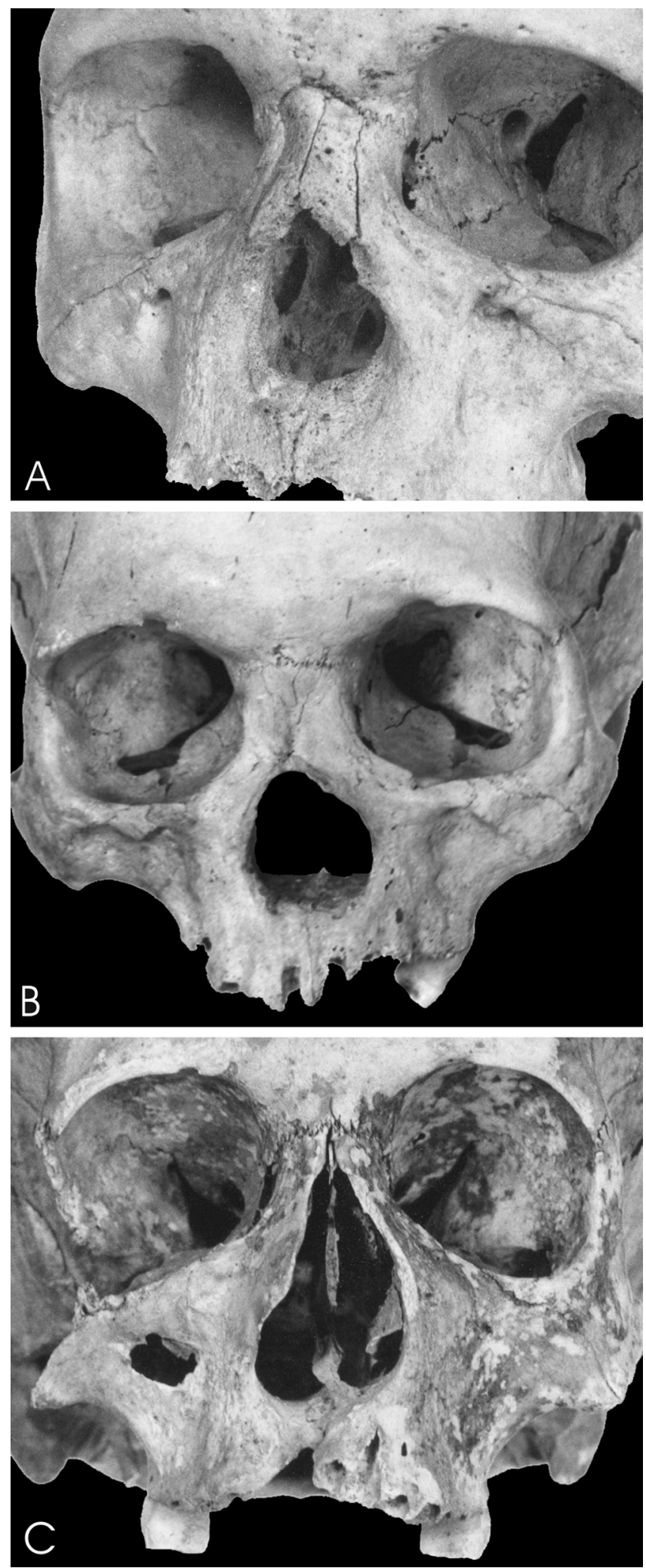

Figure 2. Palatonasal destruction caused by leprosy (A), syphilis (B) and by fracture of maxilla (C). (Křtiny Ossuary, $14^{\text {th }}-18^{\text {th }}$ centuries).

whole skeleton and a histological examination of the bone tissue from the nidus edge may contribute to the confirmation of a tumour diagnosis. 
It is not difficult to diagnose traumatogenic deformations in the nasal and palate areas in cases of healed fractures with a clearly visible fracture line of typical outline. These are known from routine clinical cases, such as case of Le Fort fractures of facial skeleton for example. Traumas are a considerable diagnostic problem in the cases of absence of traces of healing. It is the most difficult task to distinguish a perimortal injury (occurring shortly before the death) and a postmortal bone affliction. In case of perimortal fractures, sharp, smooth and usually skewed fracture edges are characteristic, from which other cracks run out in perpendicular directions. Individual fragments of fractured bones can be put together without larger gaps mostly. In case of postmortal fractures, loss of bone elasticity manifests itself distinctly; fracture edges are irregular, even forked, little skewed, and with rather a blunt end. There are no accompanying cracks here as a rule and bones may pulverize in the place of the fracture so that individual bone fragments cannot be put together exactly. However, these criteria cannot be applied reliably always. There are cases where fractures took place after the death but at a time when the bone had not yet lost its original elasticity. As a result, the identification of these fracture types is considerably limited, even though there are exceptions (for example the presence of an instrument that caused the injury).

\section{Final diagnosis}

The final diagnosis is made after the assessment of data acquired from differential diagnostics, by a detailed examination of pathological changes as well as taking all circumstances into account. However, the presence of a particular illness can be proven in only a limited number of cases.

\section{Conclusion}

No anthropological study of a population is complete without a detailed palaeopathological analysis of skeletal remains. We must proceed to determine a diagnosis using common medical practices, paying attention, however, to the specifics of the skeletal sets. A thorough knowledge of individual development stages of the skeleton and of the spectrum of illnesses manifesting themselves osteologically is a must (an anthropologist should pass classes in palaeopathology at a minimum and cooperate with a physician). It is also very important to examine all bones preserved, not only those that show morphologically visible changes. Consultation with colleagues from the discipline concerning unclear cases, at workshops, or through the professional press, are very good methods of verifying the correct diagnosis.

\section{Acknowledgement}

The research has been supported by grant No 409/07/0477 of the Grant Agency of the Czech Republic.

\section{References}

BACH, H. 1965: Zur Berechnung der Körperhöhe aus den langen Gliedmassenknochen weiblicher Skelette. Anthropologischer Anzeiger $29,12-21$.

BREITINGER, E. 1937: Zur Berechnung der Körperhöhe aus den langen Gliedmassenknochen. Anthropologischer Anzeiger 14, 249-74.

ČIHÁK, R. 1987: Anatomie 1. Avicenum. Zdravotnické nakladatelství Praha, 114.

ČERNÝ, M. 1971: Určování pohlaví podle postkraniálního skeletu. In: Symposium o určování stáři a pohlaví jedince na základě studia kostry. Praha, Národní muzeum, 46-62.

FLORKOWSKI, A., KOZLOWSKI, T. 1994: Ocena wieku szkieletowego dzieci na podstawie wielkosci kosci. Przeglad Antropologiczny 57 (1-2), 71-86.

HACKETT, C. J. 1976: Diagnostic criteria of syphilis, treponarid and yaws (treponematoses) in dry bones, and some implications. Sitzungsberichte der Heidelberger Akademie der Wissenschaften, MathematischNaturwissenschaftliche, Klasse 4, Berlin and New York, Springer.

HORÁČKOVÁ, L., STROUHAL, E., VARGOVÁ, L. 2004: Základy paleopatologie. Panoráma biologické a sociokulturní antropologie. Brno, Nadace Universitas Masarykiana, Edice Scientia.

HOWELLS, W. W. 1964: Détermination du sexe du bassin par fonction discriminante. Bulletins et Mémoires de la Société d'Anthropologie 7, 95-105.

LOTH, S. R., HENNENBERG, M. 1996: Mandibular Ramus Flexure: A New Morphologic Indicator of Sexual Dimorphism in the Human Skeleton. American Journal of Physical Anthropology 99 (3), 473-485.

LOVEJOY, C. O. 1985: Dental Wear in the Libben Population: Its Pattern and Role in the Determination of Adult Skeletal Age at Death. American Journal of Physical Anthropology 68 (1), 47-56.

KNUSSMANN, R. 1988: Anthropologie. Handbuch der vergleichenden Biologie des Menschen. Band l. Wesen und methoden der Antropologie. Gustav Fischer Verlag, Stuttgart, New York.

MARTIN, R., SALLER, K. 1957: Lehrbuch der Anthropologie in systematischer Darstellung. Band I. Gustav Fischer Verlag, Stuttgart.

STLOUKAL, M., DOBISÍKOVÁ, M., KUŽELKA, V., STRÁNKSKÁ, P., VELEMÍNSKÝ, P., VYHNÁNEK, L., ZVARA, K. 1999: Antropologie. Př́ručka pro studium kostry. Národní muzeum, Praha, 387-389.

STROUHAL, E., NĚMEČKOVÁ, A. 2008: Trpěli dávni lidé nádory? Nakladatelství Karolinum.

UBELAKER, D. H. 1987: Estimating Age at Death from Immature Human Skeleton: An Overview. Journal of Forensic Sciences 32 (5), 12541263.

VARGOVÁ, L., HORÁČKOVÁ, L. 2008: Metody zpracování anamnestických údajů v paleopatologii. Ve službách archeologie 1/2008, 242-251.

VARGOVÁ, L., HORÁČKOVÁ, L., NĚMEČKOVÁ, A. 2002: Slavonic burial site at Olomouc-Nemilany (morphological and paleopathological analysis). Antropologie XL (2), 145-155. 